\title{
Impacts of Marine Waste, Ingestion of Microplastic in the Fish, Impact on Fishing Yield, M'diq, Morocco
}

\author{
Adel Alshawafi ${ }^{1 *}$, Mohamed Analla ${ }^{1}$, Ebrahim Alwashali ${ }^{2}$, Mariem Ahechti $^{3}$ and \\ Mustapha Aksissou ${ }^{1}$ \\ ${ }^{1,3} \mathrm{PhD}$ student, Professor, Laboratory of Environment, Biodiversity and Ecology, Faculty of Sciences, Abdelmalek Essaadi \\ University, 93030 Tetouan, Morocco. \\ ${ }^{2}$ PhD, Laboratory of Nutrition, Health and Environment, Faculty of Sciences, Ibn Tofail University, Kenitra 14000, Morocco
}

Received: June 28, 2018; Accepted: July 12, 2018; Published: July 28, 2018

*Corresponding author: Adel Alshawafi, PhD student, Laboratory of Environment, Biodiversity and Ecology, Faculty of Sciences, Abdelmalek Essaadi University, BP. 2121 M'HannechII, 93030 Tetouan, Morocco, E-mail: adelman11@hotmail.com

\section{Highlights}

The marine waste impact on the environment

The economic impact of marine waste on fishing yield

Study of the phenomenon of ingestion of microplastic in fish in the Mediterranean Sea, Morocco

\begin{abstract}
Marine pollution has always shown many impacts on the environment all around the world. In this study, two of the impacts of debris are evaluated on the northern coast of the Mediterranean Sea in Morocco. The evaluation of the ingestion phenomenon of micro plastic in the fish, demonstrated that $10 \%$ was the percentage of fish samples which ingested microplastic for both species with higher values for the benthic fish, Diplodus cervinus, for the pelagic fish, Auxis thazard. The other impact detected is the presence of marine litter; $86 \%$ is the percentage of occurrence of waste in the fishing nets, which means the accumulation of debris in the seabed. This growth of marine litter leads to increased risk for marine biology in general, and to the appearance of other negative effects; in particular the low economic yield of this maritime activity.
\end{abstract}

Keywords: Impact; ingestion; microplastic; Diplodus cervinus; Auxis thazard; yield;

\section{Introduction}

The harmful effects caused by marine waste which is disposed of in the oceans and seas is a problem significant world, this litter is present on beaches or floating in oceanic waters or benthos seas. Items of debris are now found in marine habitats throughout the world, from the poles to the equator, from shorelines and estuaries to remote areas of the high seas, and from the sea surface to the ocean floor $[32,35,48,49,62,68]$. Many of the risks of the spread of waste in the marine environment arise It is known to be harmful to organisms, human health through the potential to transport contaminants, addition to loss of biodiversity [22,29,38,44,51,57,79,80].

It also includes major threats at the present to marine biodiversity the effects of climate change, ocean acidification, invasive species, overfishing and other extractive activities, pollution and marine debris, habitat degradation, fragmentation and loss, human population expansion, tourism, and the impact of a wide range of human activities in the coastal zone $[37,42,55,61]$. Approximately $75 \%$ is plastic in nature but to a dynamic force nature of the ocean and sea surface, and the large area involved, it is also difficult to know where the debris accumulates, and thus where it will cause the greatest impacts $[45,72]$.

There are many impacts of marine debris on humans, the marine ecosystem, and economically. In 2008 alone, they were estimated at $\$ 1.26$ billion per year for the 21 Asian and Pacific economies [53]. These costs appear from a number of different sources. Wastes can directly damage ships participating in leisure, transport or fishing. In addition to the direct damage to ships as a result of marine debris barriers, hidden nets and other fishing gear can have implications for fish industries by reducing levels of target stocks, prey and habitat damage [52]. The debris can also be detrimental to the tourism industry by reducing or altering beach visits, as well as potential losses of private sector investment in dirty or contaminated areas $[9,63]$. Direct impacts on human health can result from abandoned sharp tools, marine interactions between ships and large floating debris [77] and are likely to cause exposure to biphenyls, phthalates and other plastic additives [81]. The direct implications to wildlife fall under many main categories; poisoning of chemicals in marine wastes, Suffocation, entanglement, and ingestion, though debris can also indirectly impact marine life through alteration of habitat and transport of invasive species $[10,69]$. Over 660 species are recorded to have been affected by marine debris entanglement or ingestion [45]. About $15 \%$ of the species affected through entanglement and ingestion are on the IUCN Red List. Of particular concern are dangerous the Extinction $[59,83]$. Undirected impacts macro and micro plastic is not an inert material, and on top of its own toxicity it has the potential to agglomerate and transport Persistent Organic Pollutants (POPs) in the forms of Polychlorinated biphenyls (PCB), Hexa 
chlorocyclo hexane $(\mathrm{HCH})$, and the pesticide Dichloro Diphenyl Trichloroethane (DDT) $[20,43,73]$.

More than studies have shown that marine life, including seabirds, sea turtles, fish, marine mammals, sharks, and plastic eating $[5,8,11,17,21]$. resulting in a lot of physiological and chemical damage Where leads ingestion micro debris to suffocation or gastrointestinal obstruction then die As the case with albatross birds which died most cases Because of the false sense of fullness, They also found large numbers of dead fulmars fish due to ingested her the micro wastes, additionally the nanoplastic which leads to Inhibiting photosynthesis in algae $[6,14,15,16,18,23,76,84,86]$. Countries also suffer from economic damage caused by marine wastes such as the financial cost of cleaning the coastline is very expensive as well as the low yield of fishing (Association Mer Terre). Lost fishing gear threatens marine life. Comprehensive data on ghost fishing impacts are not available, but entanglement in or ingestion of, human caused debris (including fishing gear and many other items) has been reported for over 250 marine species and the emergence of many marine wastes in fishing nets when they are released from the sea $[47,60]$.

\section{Methodology}

\section{Study area}

M'Diq is located $7 \mathrm{~km}$ from the city of Tetouan and $25 \mathrm{~km}$ from Ceuta. Having as geographical coordinates $35^{\circ} 41^{\prime} \mathrm{N} 5^{\circ} 19^{\prime} 31 \mathrm{~W}$, Mdiq is bounded on the north by the Fnideq municipality, on the south by the Mallaliyine commune, on the west by the Alleyine commune and on the east by the Mediterranean Sea. M'Diq covers an area of 480 hectares of which 153 hectares are urbanized. It has been recorded a population of 56,227 in the Moroccan census 2014 [56,67]. and hosts more than 100,000 tourists each year. Mdiq is an ultimate seaside destination; one of the most important tourist attractions is the M'diq La Semaine Nautique Internationale (SNIM), organized once a year by the M'Diq Royal Yachting Club and sponsored by several commercial companies. It is also important for all surrounding socio-cultural activities (Figure 1). The town's harbour is split into two parts: one for tourism and the other for fishing. Both have been expanded recently in order to improve tourist offerings and to increase the harbour's capacity. M'Diq is a popular weekend destination for residents of nearby Ceuta. Boats up to 50 metres long with

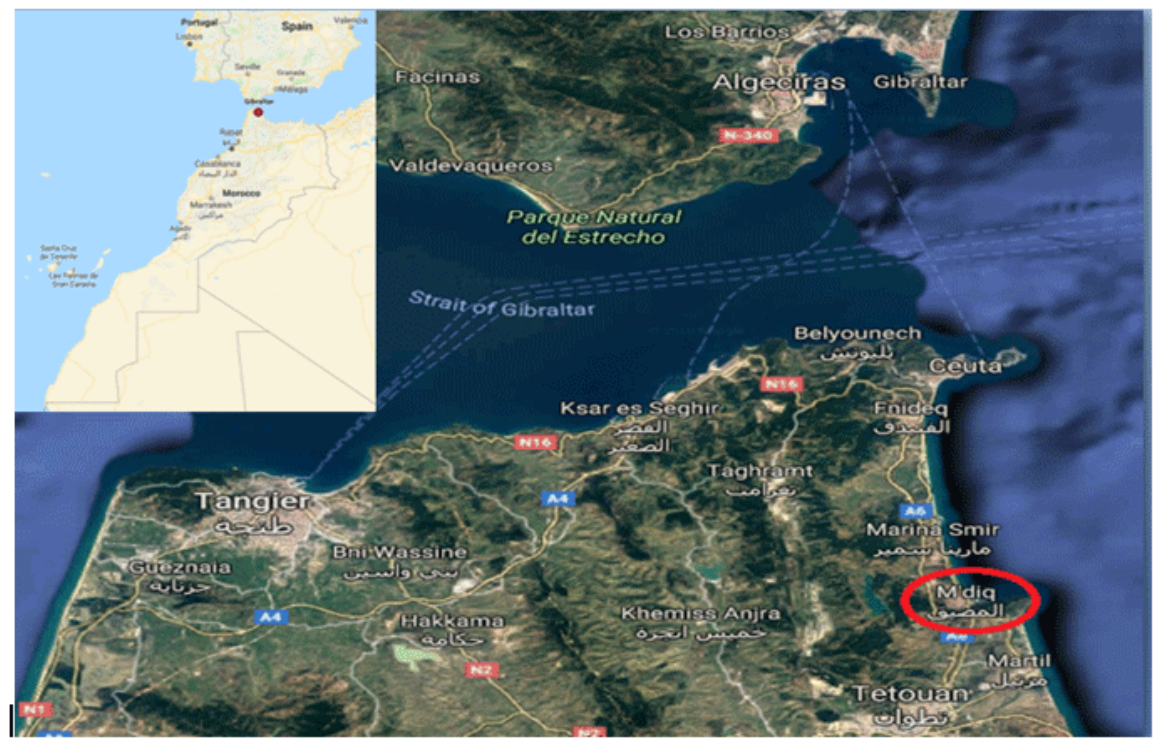

Figure 1: M'diq beach in Morocco, study area (Google Map).

a depth of nearly five metres can be moored (Morocco - Punta Almina to Oued Kiss Sector 2012). From the climatic point of view that oceanographically and biological: crossroads enters the south of Europe and the north of Africa. Zone of crossing of migratory roads of the birds, fishes and the marine mammals, a place where animal and vegetable communities coming from distinct ecosystems mix between them, a place where the endemism abound, where the biodiversity appears extremely generous [31].

The quantity of waste M'diq indeed, 55 tons per day in normal period. In summer, it is increased to more than 90 tons per day. Studies are currently underway for the delegation of this service to the private sector [31]. Fishing is developed all along the coast of Tetouan and catches are landed especially in the port of M'diq, the rest at the new landing point of Fnideq. Fishing activity constitutes at the local level an economic pole of paramount importance because of the number of fishing units and the quantities landed. It is also very important in terms of employment; it occupies about $20 \%$ of the active population. The sector generates significant revenues for trawlers, purse seiners, long liners and 400 fishing boats [13]. 


\section{Sampling}

There are a lot of evidences for ingestion micro plastic by marine habitats; a range of marine taxa, including birds, sea turtles and marine mammals, are known to be affected by ingestion $[29,47,72]$. Studies over the past decade have shown that micro plastics are widespread in the marine environment, at the sea surface on the sea bed and that their abundance has increased since the 1960s. We were chosen on the fishes for study ingestion phenomenon for micro plastic. The study was conducted at during January to April 2017 on two, (Table 1) (Figure 2). For this study, fish were collected from coastal waters of the Mediterranean sea, during a period of four months (January to April 2017), to do that, two species of fish spread on the northern shores of the Mediterranean Sea; Auxis thazard \& Diplodus cervinus, have been chosen to evaluate the negative impacts for debris on the northern coast of the Mediterranean sea in Morocco.

\begin{tabular}{|c|c|c|}
\hline \multicolumn{3}{|c|}{ Table 1: Scientific classification of study samples of fish. } \\
\hline Scientific classification & Auxis thazard & Diplodus cervinus \\
\hline Kingdom & Animalia & Animalia \\
\hline Phylum & Chordata & Chordata \\
\hline Class & Actinopterygii & Actinopterygii \\
\hline Order & Perciformes & Perciformes \\
\hline Family & Scombridae & Sparidae \\
\hline Subfamily & Scombrinae & - \\
\hline Tribe & Thunnini & - \\
\hline Genus & Auxis & Diplodus \\
\hline species & - & D. cervinus \\
\hline Subspecies & A. thazard thazard & - \\
\hline & Trinomial name & Binomial name \\
\hline & Auxis thazard & Diplodus cervinus \\
\hline & thazard & \\
\hline
\end{tabular}

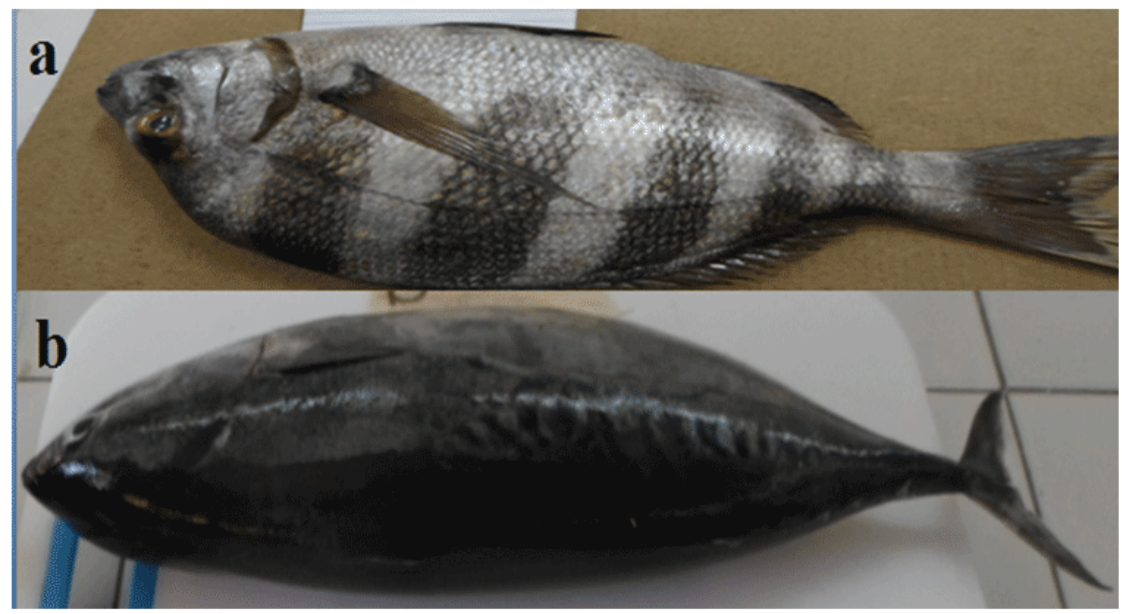

Figure 2: Fish samples (a) Diplodus cervinus (b) Auxis thazard (source alshawafi).

After recovering the fish from M'diq port and bringing them back to the laboratory, a number of morphological measurements were noted; for each fish, basic morphological measurements were recorded such as body weight and length and codificated this data for each sample. Gastrointestinal tracts were removed by dissection, from each fish; to minimize the risk of contamination, fish were opened with a scalpel and digestive tracts were immediately placed into clean Petri dishes for inspection with a dissecting microscope.

The next step is to dissect the fish, producing a longitudinal incision along the belly of the fish, cutting the skin and muscles with the chisel from the mouth to the anus. Stopping at $1 \mathrm{~cm}$ from the end of the jaw, without damaging the underlying organs, the fish is fully opened at the posterior end of the ventral opening until to incise the dorsal muscle. The same incision should be made just behind the operculum. Once opened, the viscera are extricated; the stomach is opened and emptied of its contents into a Petri dish previously washed and filled with distilled water in order to make a first sort of small waste that can float on the surface of the water, then empty the contents using a filter with a diameter of less than $1 \mathrm{~mm}$ and the suspended solids trapped on the filter are transferred to a petri dish for examination under a microscope, in search of small plastic parts and placed in a closed glass case got. The data obtained was transformed and formatted with the Excel program in order to subsequently convert them into graphs; and illustrate the changes and relationships between samples, then analyze them using statistical tests using SPSS programs (Figure 3). 


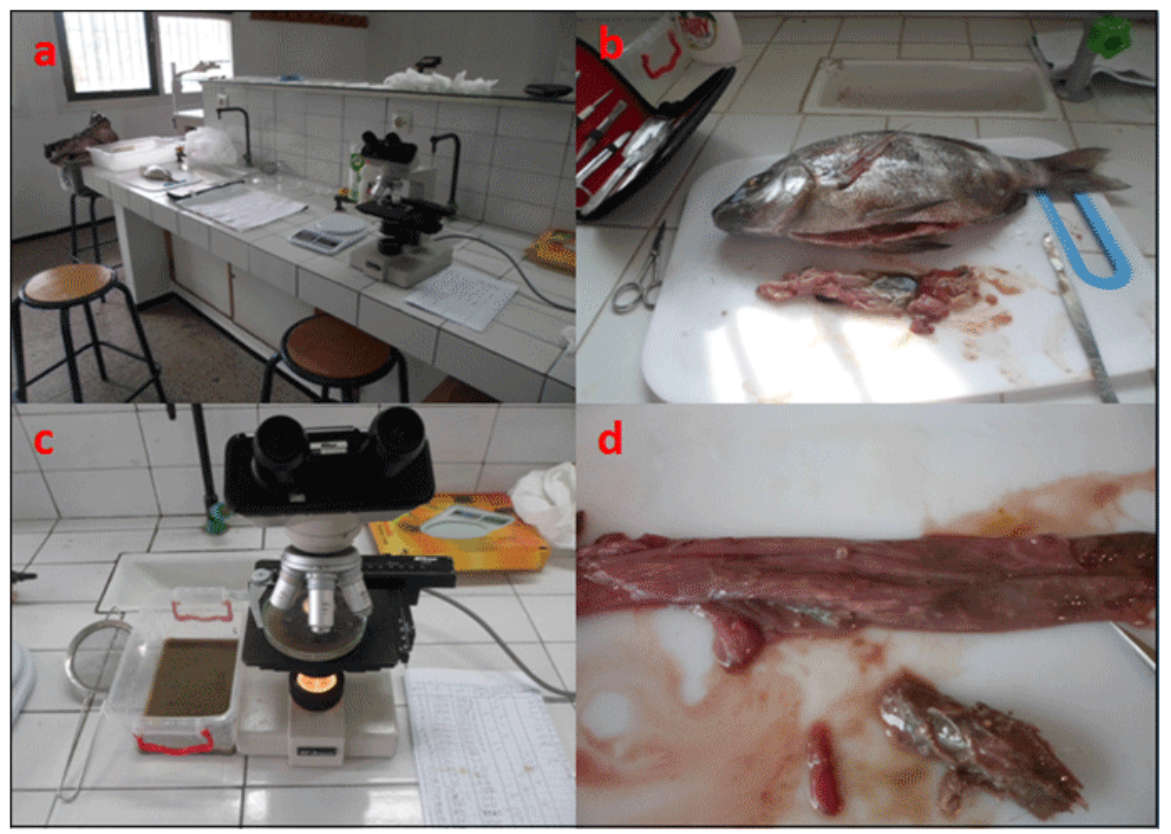

Figure 3: (a) the Tools used at dissection process, fish samples, (b) image sample fish dissection in the laboratory, (c) use microscope in search process on micro plastic at stomach, (d) The stomach and content of food which inside, small fish, plankton Ect.

\section{The impact on fishing yields}

A large number of marine litters have been found by fishermen when they are fishing with sea-nets, which affects fishing yields and thus the financial performance of fishermen. In order to assess the existence of a real economic impact of marine litter on fishing performance, we conducted a study to evaluate the presence of waste in fishing nets, where we conducted about 30 waste monitoring. the fishing nets when they are removed from the sea along the coast of the city of M'diq, the process starts from the beginning of the stream throw in the sea, and then wait until the fishermen dock the nets, then we record the weight of the fish caught using the weighing devices as well as the weight of the waste and we record the data, after this step we classify the waste obtained in main elements such as plastic, metal , glass, fabric ... etc) and we record the result of sorting and organize them using specialized programs such as Excel and SPSS (Figure 4).

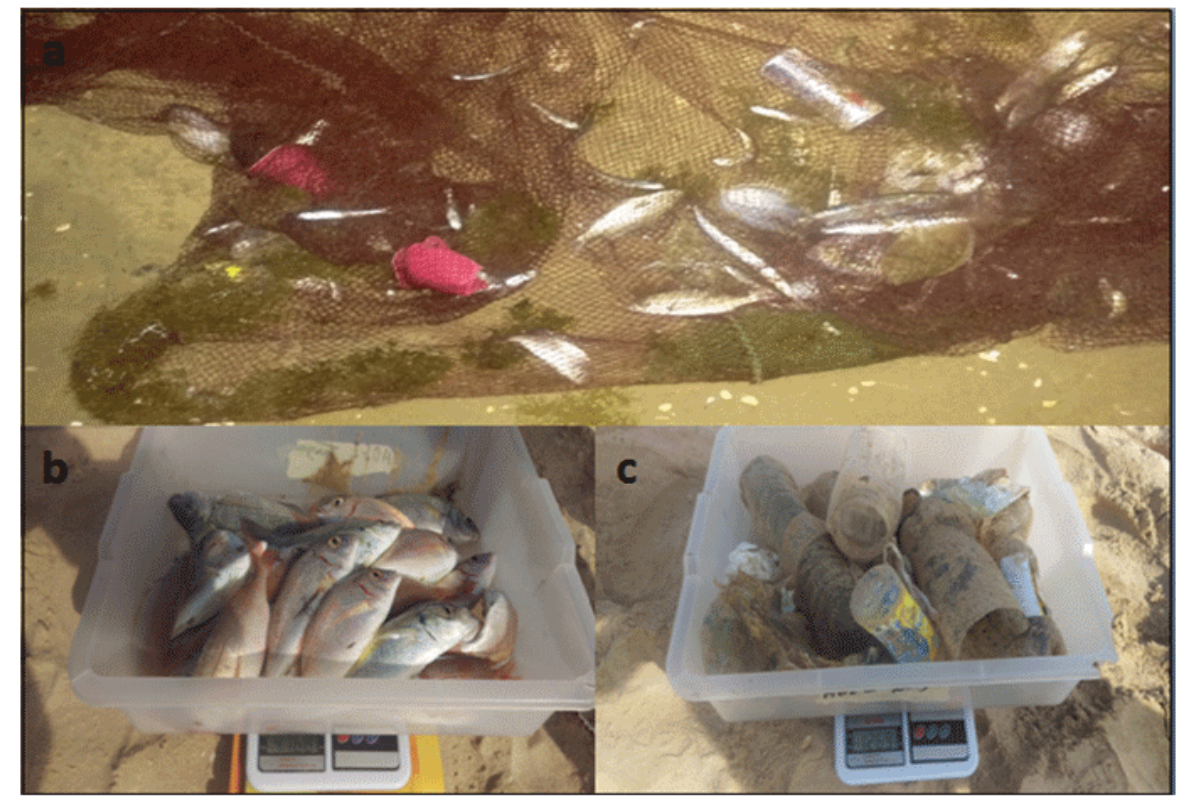

Figure 4: (a) the marine waste in the nets (b) Fish weight process (c) waste weight process. 


\section{Cluster analysis}

All data obtained from the samples were statistically calculated, analysed and compared using Microsoft Excel software. In the second step, we used the principal components analysis Independent Samples Test and (ANOVA) which is a multivariate statistical method to determine a system of reference axis prioritized and The Levene's test was used to assess of the homogeneity of variances for all dependent variables (test $\mathrm{P}<$ $0.05)$, also we used test correlation between the variables.

\section{Results and discussion}

\section{Ingestion Phenomenon}

\section{Auxis thazard thazard}

This species is present in the Atlantic, Indian, and Pacific oceans. It is considered vagrant in the Mediterranean Sea. However, there are only a few records of this species in the Atlantic as most of the Auxis in the Atlantic are Auxis rochei. The Eastern Pacific population is recognized as a subspecies, Auxis thazard brachydorax [19], which occurs from California to the mouth of the Gulf of California to Peru, and all the oceanic islands except Clipperton [70]. In the Mediterranean, this is a common species in fisheries and abundance changes from place to place every year [30]. This is a pelagic, oceanodromous species that is also epipelagic in neritic and oceanic waters [25]. Adults are coastal or near-coastal, while juveniles are more widely spread throughout the world's ocean. It feeds on small fish, squids, planktonic crustaceans (megalops), and stomatopod larvae. Because of their abundance, they are considered an important element of the food web, particularly as forage for other species of commercial interest. It is preyed upon by larger fishes, including other tunas and billfishes. Average estimated length-age relationships in the equatorial Atlantic are $22.9 \mathrm{~cm}$ at one year, $30.4 \mathrm{~cm}$ at two years, $36.7 \mathrm{~cm}$ at three years and $40.4 \mathrm{~cm}$ at four years [40]. This species of fish is also listed in the red list $[46,82]$. During our work, from thirty samples of Auxis thazard mackerel (Melva) were dissected, three showed a microplastic existence in the stomach. Despite the ingestion of plastic pellets, with a stomach full of food. At thirty samples of Auxis thazard thazard it was the length mean for fish $38,833 \mathrm{~cm}$, and the wiegth it was $1138 \mathrm{~g}$ (Figure 5).

\section{Diplodus cervinus}

The Diplodus cervinus is found mainly in the eastern Atlantic, from the Bay of Biscay to South Africa. It can also be find in the Mediterranean. The Diplodus cervinus is a fish of 10 to $40 \mathrm{~cm}$ of common length, up to $55 \mathrm{~cm}$. Like all Sparids, it only has one dorsal fin. The body is oval, raised and compressed laterally. The lips are thick. Diplodus cervinus is omnivorous and eats all he can swallow with preferences for isopods and polychaete worms, not disdaining some algae. Adult, becomes a benthic carnivore and as evidenced by the presence of incisors and molars, tends to feed on bivalve molluscs, sea urchins, polychaete worms and crustaceans [64,85], Sparida fish samples recorded the length mean 31,833 $\mathrm{cm}$, and it was the weight mean 757,333 g (Figure 5).

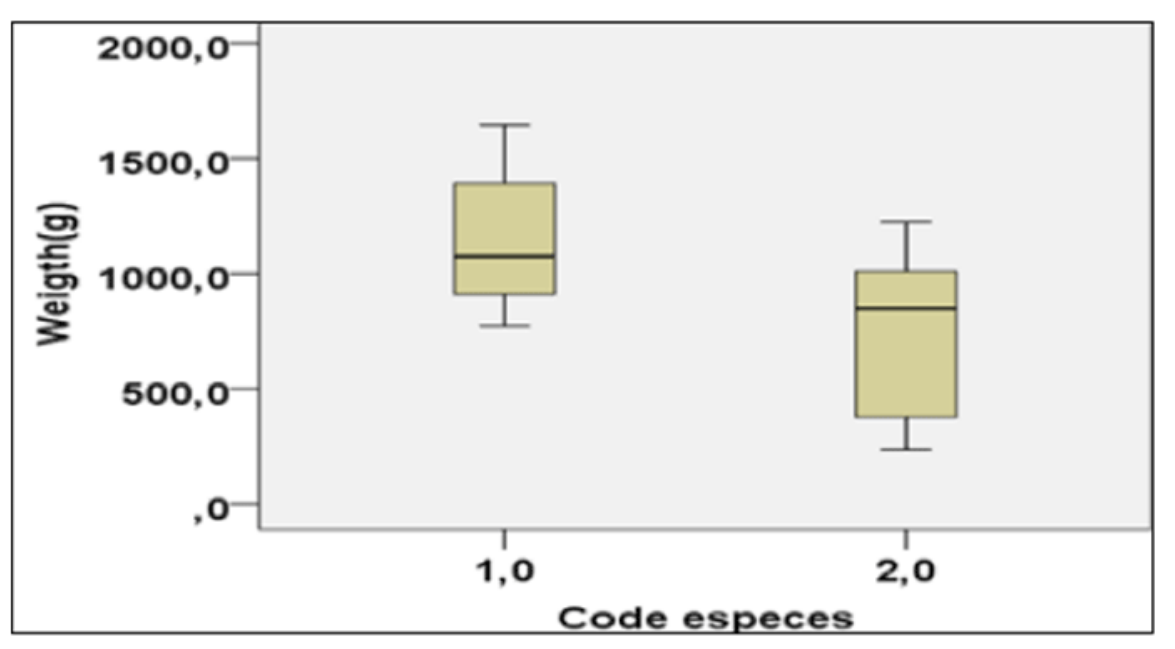

Figure 5: The weight Mean for two fish samples (1) Auxis thazard (2) Diplodus cervinus.

From thirty samples of the species of Auxis thazard thazard (Melva) that were dissected, three samples indicated an ingestion of micro plastics by storing micro pellets in the stomach, these samples were in good health, and their stomachs were full of food. The other individuals of the species Diplodus cervinus, four samples showed ingestion of micro plastics from about thirty samples that had been dissected before, so their stomachs were full of small fish, plankton and small marine organisms. Thousands of small pieces from marine litter are found as a result of degradation process. This process takes longer in the ocean and sea than on land due to lower temperatures $[2,78]$. This small debris cause direct impacts on the marine organism for example the entanglement due to ingestion $[17,65]$.

The ingestion of plastic may be direct or indirect; [26] directly from floating debris on the sea surface or in a water column, or from marine waste on the seafloor, and indirectly ingestion can take place as a result of feeding based on small fish or plankton that contain plastic debris. Ten percent of the overall total for the fish that were studied ingested microplastic waste. Studies have shown that marine life; including sea birds, sea turtles, fish, marine mammals, and sharks, eat plastic (Figure 6). 


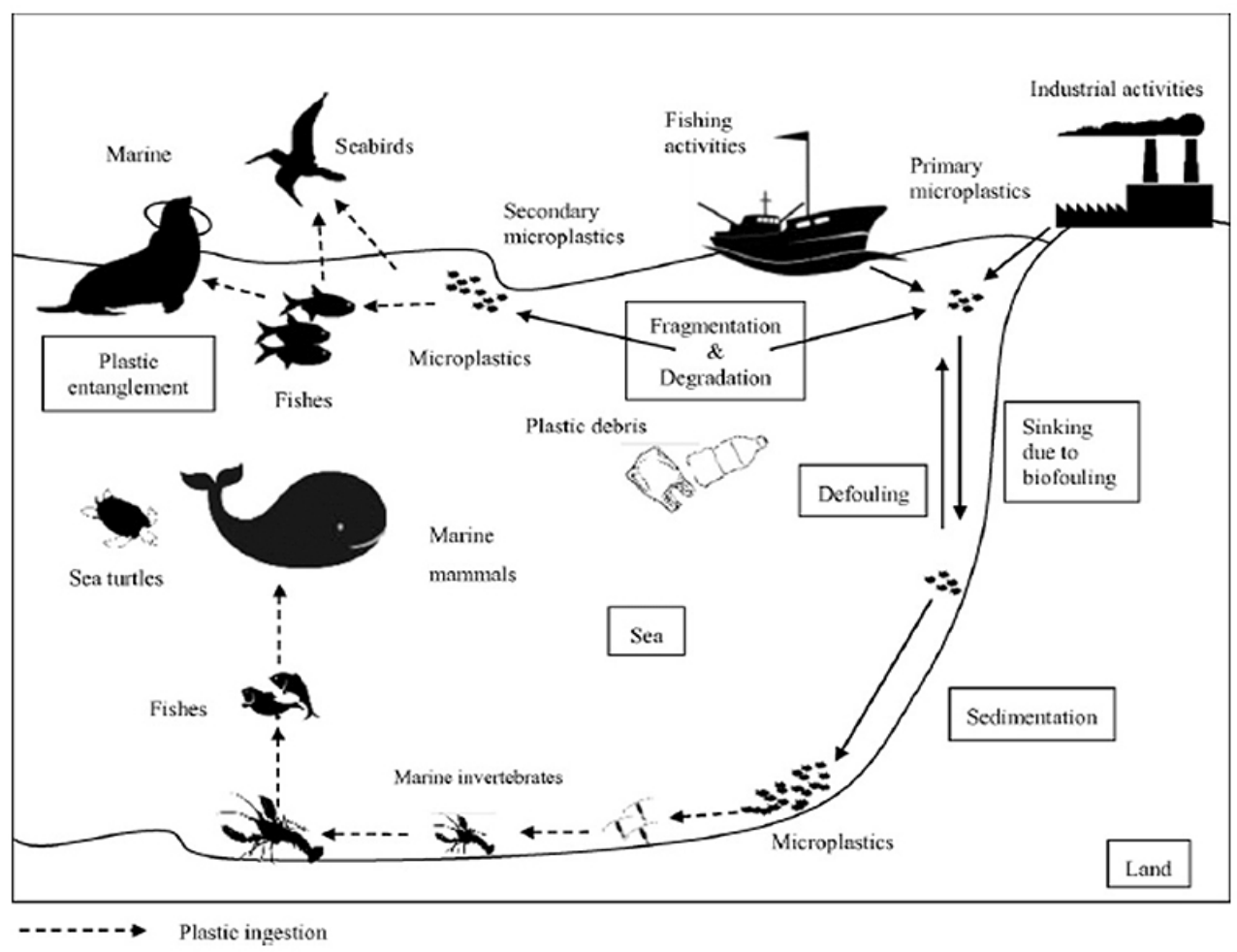

Figure 6: Potential pathways of plastic debris transportation and its biological, process ingestion micro plastics (source: Wright et al., 2013).

Many studies confirm Ingestion Phenomenon Microplastic by fishes, may be an emerging environmental crisis because of the proliferation of plastic pollution in aquatic environments. Plastic accounts for $92 \%$ of all encounters between organisms and marine debris, the effects of large plastic items (i.e., macro plastic), such as entanglement, ingestion and death, being widely reported in fish and wildlife [36]. However, a greater proportion of plastic pollution is microscopic b5 mm; [3]. Some micro plastics, for instance, micro beads, are manufactured to be of a microscopic size, typically polyethylene and polypropylene and used in skin exfoliators and cosmetics and in air-blasting technology [29,33,38,39].

The occurrence of microplastic ingestion in marine environments has been well documented with a surge in research since 2000. Percent occurrences of plastics in the stomach contents of marine fishes range from $2.6 \%$ in the North Sea to $37 \%$ in the English Channel Reports from other areas include Brazilian estuaries and North Pacific Gyre [14,17,27,50,65].

In a study by a group of researchers in the Gulf of Mexico, Plastics were detected in 12 individuals (10.4\%). Percent occurrences by plastic type were $3.8 \%$ for filament plastics, $2.6 \%$ for fragment plastics, and $2.6 \%$ for film plastics for all fishes. Percent occurrences by location were 5.9\% in harbor fishes, $13.5 \%$ in the bay fishes and $22 \%$ in the offshore fishes. The maximum number within a stomach was 4 for filament plastics, 2 for fragment plastics, and 6 for film plastics. Among the 12 individuals with a plastic item, 6(50\%) contained at least two plastic types and 3(33\%) contained three plastic types.
Percent occurrence within the benthic invertivore-carnivore trophic guild was $12 \%$ also a total of 419 freshwater fishes were examined, representing 44 species and 12 families. Plastics were detected in 34 individuals (8.2\%) from urban and non-urbanized streams. Percent occurrence was $1.3 \%$ for filament plastics, $2.7 \%$ for fragment plastics, and $3.1 \%$ for film plastics for all. Although percent occurrences were low, occurrences of microplastic ingestion were ubiquitous among all water bodies, taxonomic groups, and trophic guilds quantified in this study, sparida and scrompida they was of samples which Included by the study [54].

Plastic ingestion by marine organisms is commonly reported as "mistaken identity" consumption because of its similarity to natural prey. This hypothesis is well supported in the case of sea turtles ingesting clear plastic items (e.g., plastic bags floating in the water) due to their 3D shapes and movements that are similar to jellyfish [74]. Many species of seabirds have also been found with high concentrations of micro-plastic (transparent or colored) debris in their digestive tracts, which were apparently mistaken for potential prey (e.g., fish eggs, plankton) [7,47]. Nylon ingestion by estuarine fish during suction feeding in sediments could reflect their resemblance to polychaetes [65] or to the consumption of organisms aggregated to plastic debris (mixed with natural prey items) [66]. For large fish Recent hypotheses concerning the consumption of plastic debris have considered different aspects of their predatory feeding behaviors, including opportunist strategies, accidental ingestion during feeding strikes, or the ingestion of aggregated prey items $[12,71]$.

The microplastic which existed in fish's stomach it was a 
group of fragment, pellets, and lines ranging in size between 0.5 - $4 \mathrm{~mm}$, maybe exist pellets because the region near to industrial towns Tangier, Martil and a new port Tanger Med, and Sewage discharge to the sea water in M'diq Undoubtedly, much of the sea debris at the bottom of the sea will produce a lot of small marine debris as a result of decomposition and ingested microplastic by fish's. at new study 32 of fish specimens belonging 11 species and 9 families, Plastic pellets were found in the stomachs of 7 individuals (22\%) of two species: the king mackerel, Scomberomorus cavalla (Scombridae), (Carcharhinidae) [28]. with sizes ranging from 2 to $5 \mathrm{~mm}$ in their longest dimension [26]. The plastic pellets had circular shapes, and colors ranging from clear to white, and yellowish (Figure 7).

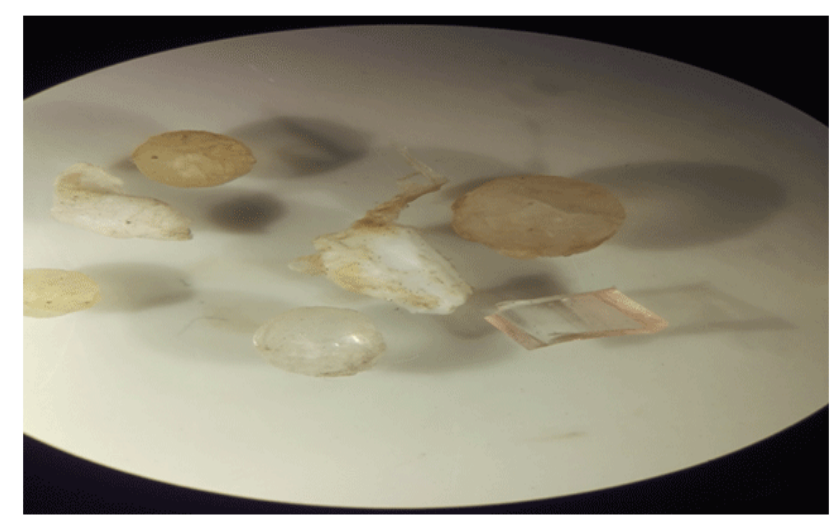

Figure 7: Microplastic, pelltes, fragments, found in fish stomach.

\section{Impact on fishing yield}

From thirty fishing processes, twenty-six processes have highlighted the presence of marine litter in the fishing net, this result has been confirmed, and most of the amount of marine debris is thrown to the bottom of the sea, (Table 2). This hypothesis is strongly supported by the marine litter found in fishing boats, in their nets during the fishing process (Figure 8).
Table 2: Fish weight and waste at each process fishing by nets.

\begin{tabular}{|c|c|c|}
\hline $\mathrm{N}^{\circ}$ & Fishs weight (g) & Wastes wieght (g) \\
\hline 1 & 42000 & 1300 \\
\hline 2 & 32000 & 1500 \\
\hline 3 & 30000 & 1100 \\
\hline 4 & 18000 & 600 \\
\hline 5 & 1000 & 2000 \\
\hline 6 & 1200 & 200 \\
\hline 7 & 200 & 150 \\
\hline 8 & 1500 & 120 \\
\hline 9 & 1000 & 250 \\
\hline 10 & 7000 & 200 \\
\hline 11 & 8000 & 2000 \\
\hline 12 & 5000 & 800 \\
\hline 13 & 3500 & 300 \\
\hline 14 & 2500 & 700 \\
\hline 15 & 38000 & 3500 \\
\hline 16 & 150 & 0 \\
\hline 17 & 950 & 60 \\
\hline 18 & 550 & 50 \\
\hline 19 & 8000 & 200 \\
\hline 20 & 2500 & 0 \\
\hline 21 & 25000 & 180 \\
\hline 22 & 8500 & 0 \\
\hline 23 & 950 & 300 \\
\hline 24 & 2500 & 230 \\
\hline 25 & 70000 & 420 \\
\hline 26 & 2000 & 120 \\
\hline 27 & 16000 & 890 \\
\hline 28 & 170 & 0 \\
\hline 29 & 3700 & 160 \\
\hline 30 & 14500 & 940 \\
\hline
\end{tabular}




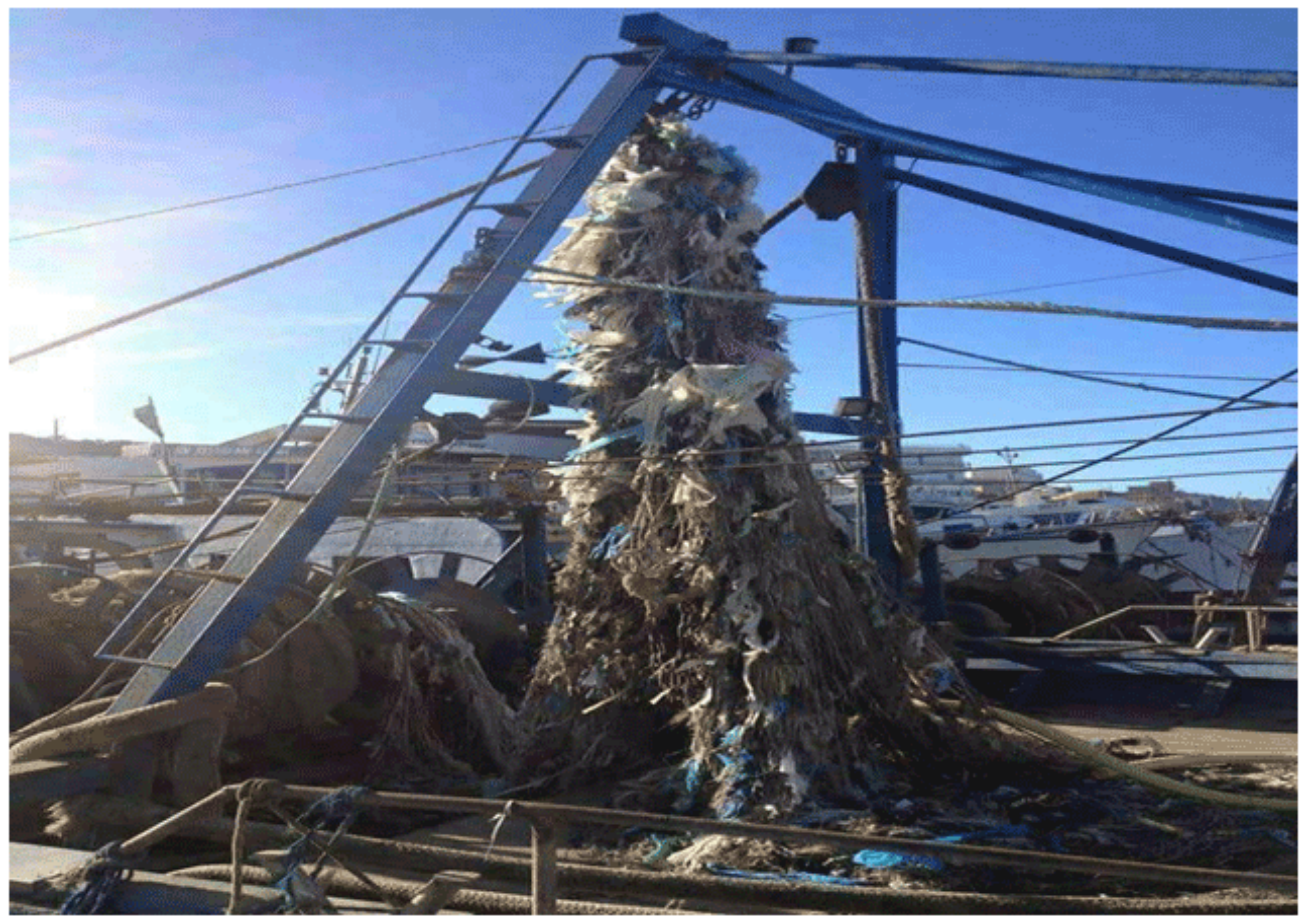

Figure 8: marine waste found at nets fisherman's by boats (by Redwan backouri).

On the one hand, the largest amount of fish recorded was $70000 \mathrm{~g}$ and the lowest quantity was $150 \mathrm{~g}$, while the average recorded was $11545 \mathrm{~g}$. the other hand, for marine litter, the highest was $3500 \mathrm{~g}$ and the minimum quantity was $150 \mathrm{~g}$ with an average of $609 \mathrm{~g}$, The percentage of marine waste at some once is very high (Figure 9,10).

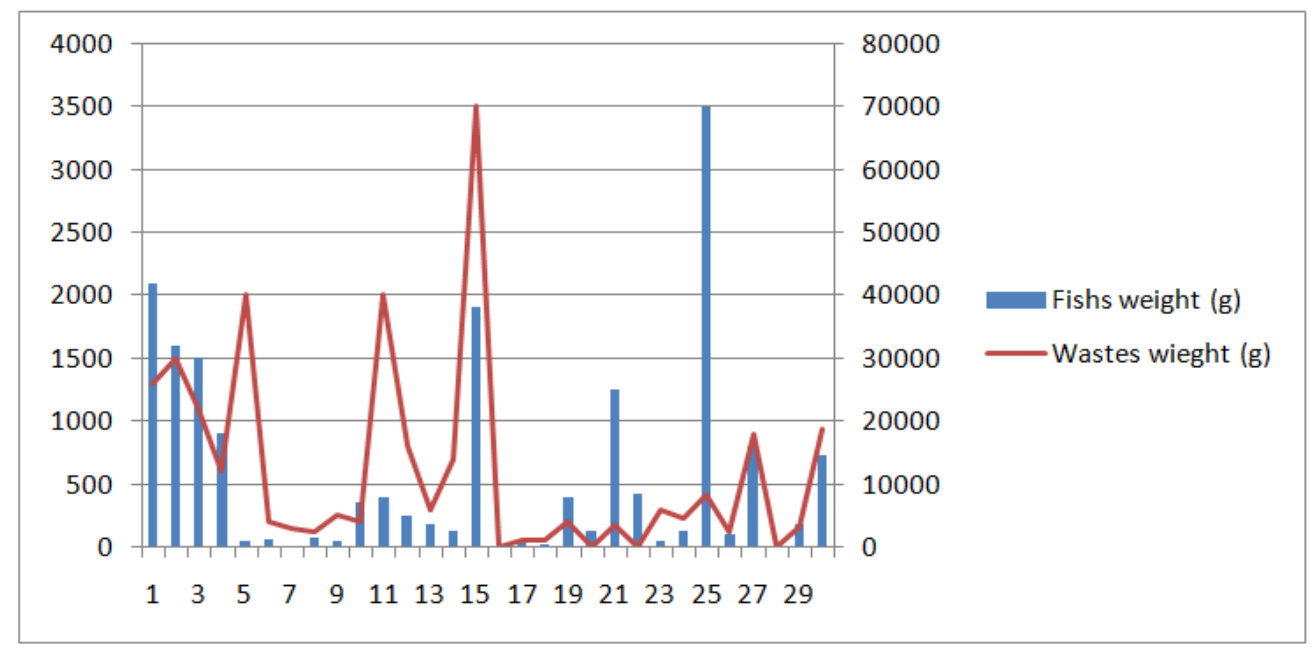

Figure 9: The variations in marine waste weight with fish weight through 30 fishing process. 


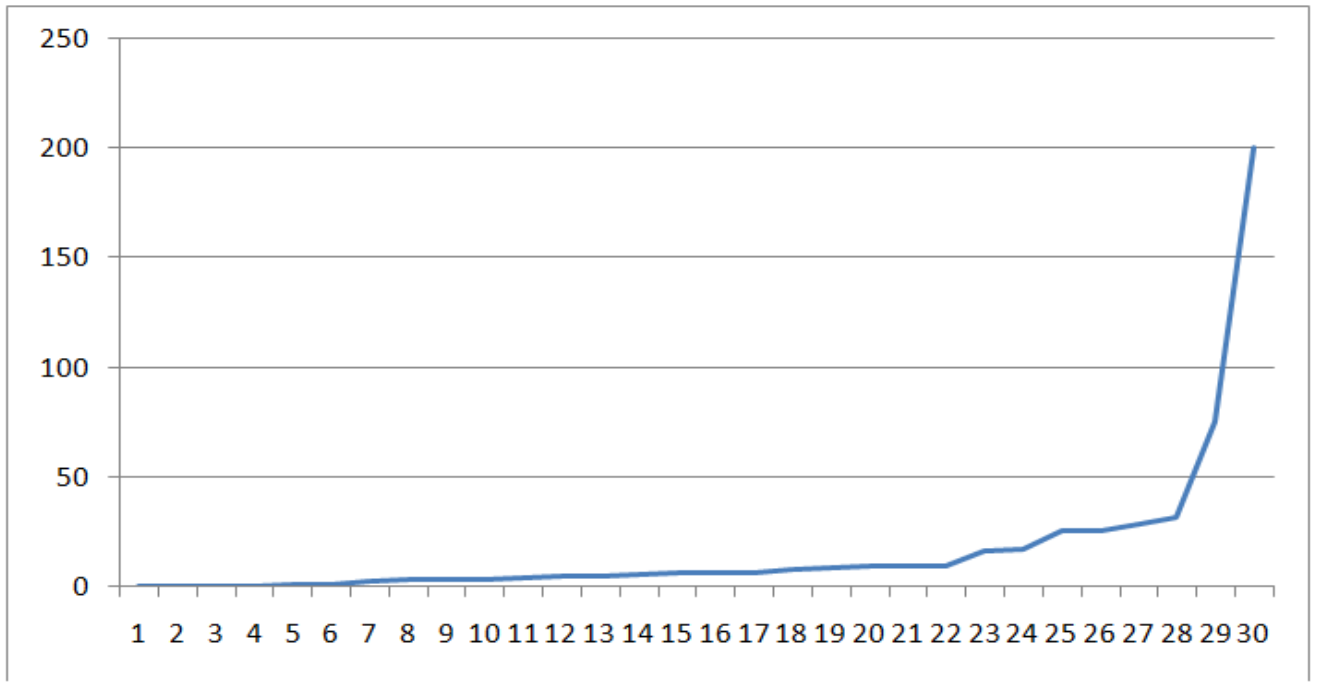

Figure 10: The percentage marine waste weight with fish weight through 30 fishing process the figure shows that the percentage reached in some cases to $200 \%$.

\section{Discussion statistic Analysis}

Statistical analysis was carried out using statistical tests software package, with the intention of studing the differences between the two species. Comparisons, variation in tall, weight, stomach status and absence or presence of plastic in the stomach between the two groups, were carried out. At the beginning, we did a test $(\mathrm{t})$, independent samples test, based on the hypothesis that the variance between the variables (fish tall, weight) and ingestion variance is not equal. At a significant level of 0.05 and through the result of the test we found that there is a significant difference between the variable (weight; 0.03), variable (stomach status; 0,000), (P-value < 0.05) which means that there are differences between the previous variables and the occurrence of the process of ingestion. Also, the results of statistical tests showed that there is a correlation between fish weight and the condition of the stomach with ingestion, where there is a significant correlation between those two variables and a lower correlation between weight and the condition of the stomach (Table 3).

Table 3: Relation of correlation between Variables four, species, ingestion, stomach status and weight

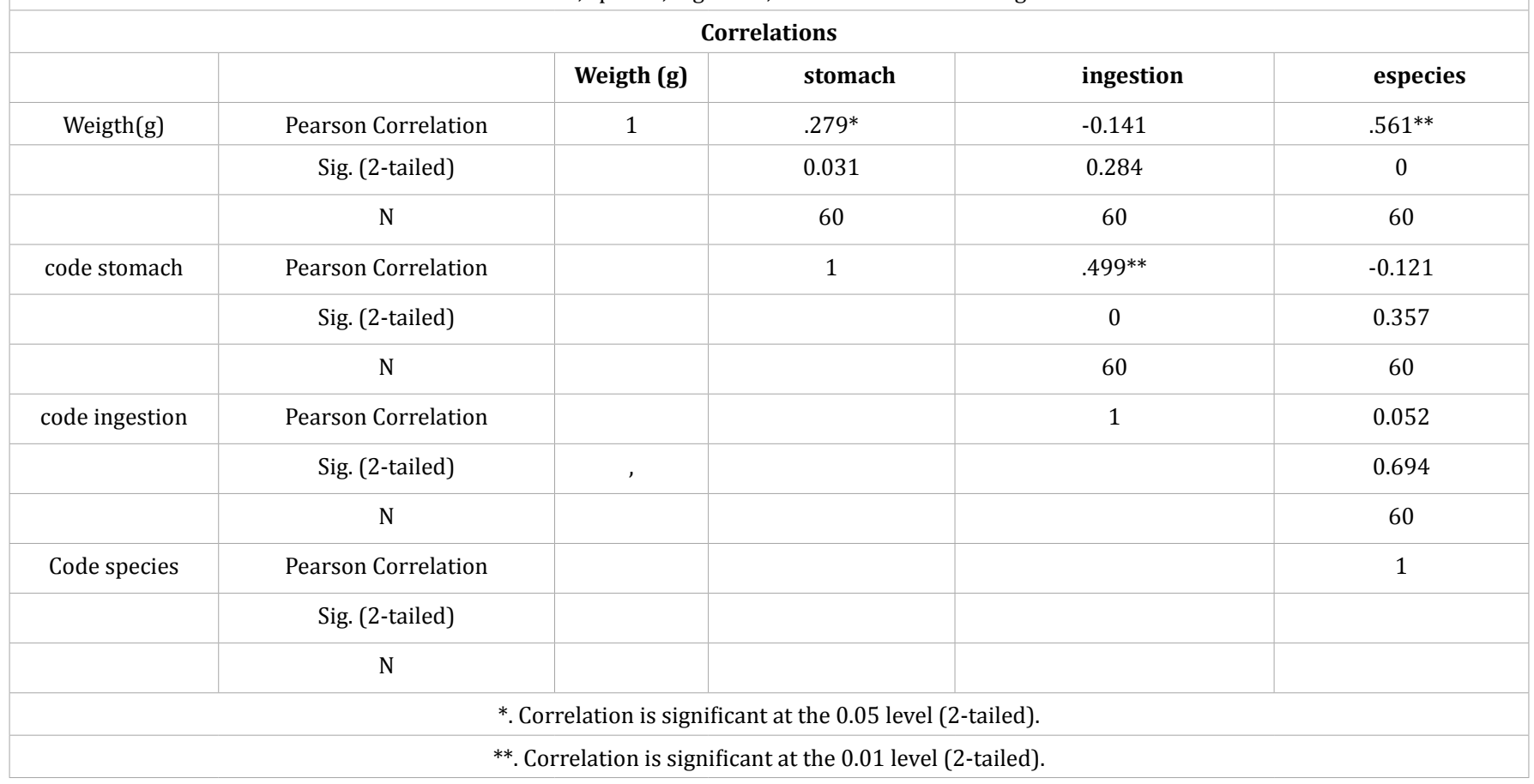


For the vast majority of fish Auxis thazard thazard, stomach status was full of food, while, for the other specie Diplodus cervinus, stomach of the vast majority was half full for cases with occurred ingestion of micro plastic for both species (Figure 11,12).

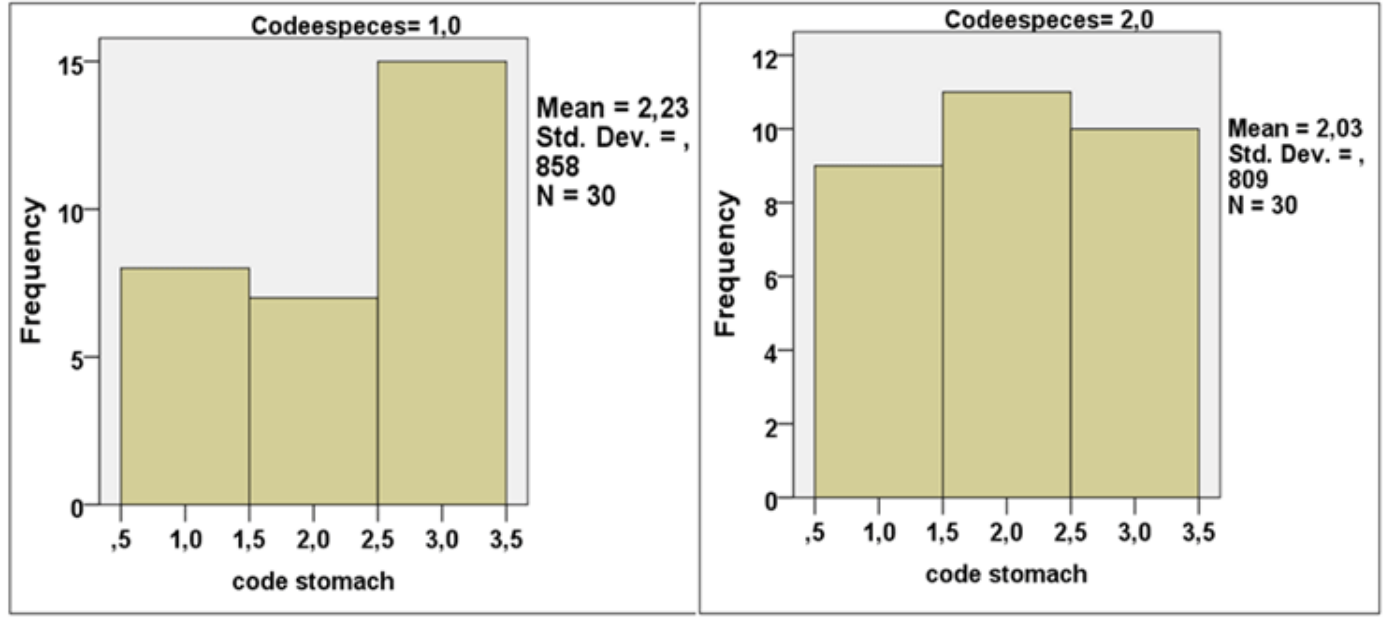

Figure 11: stomach status variations in study samples.

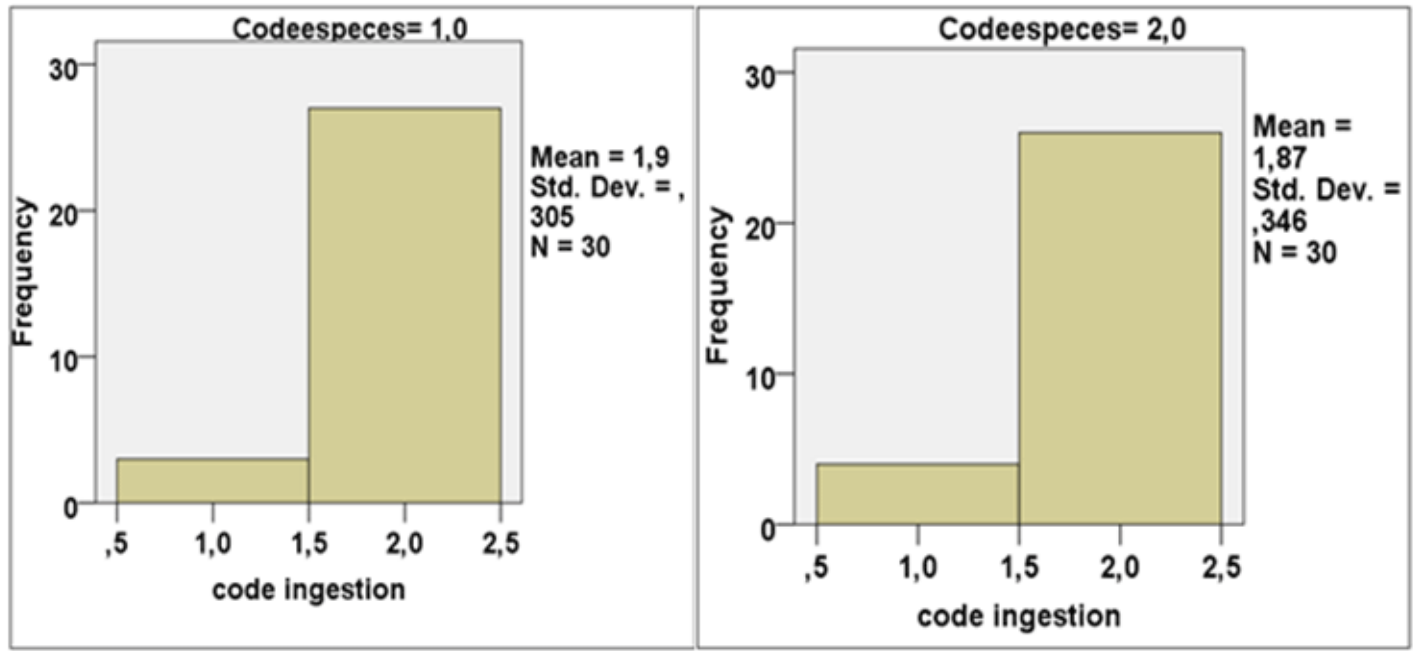

Figure 12: Ingestion process at two samples when stomach status the Full and half full.

The high rate of ingestion in benthic fish is probably due to the presence of large amounts of marine debris at the bottom of the sea. Another reason to mention; is the great similarity between the microplastic and the prey preferred by these fish. For example, the turtles eat the plastic by deceiving food, because of the great similarity with the jelly fish, another example is the ingestion of pellets by birds $[1,41,58]$. Another possibility is when fish eat quantities of plankton and small fish containing microplastic (Figure 13). 


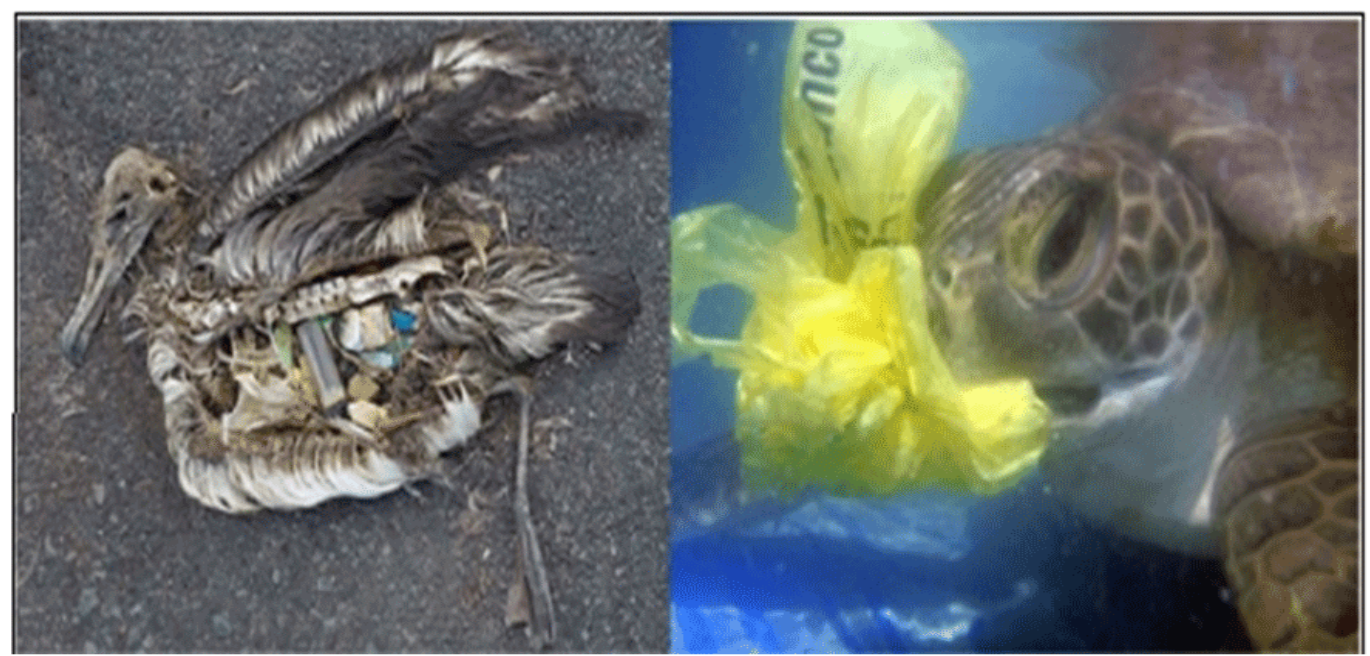

Figure 13: eat the marine waste, because of similarity with the preies.

The ANOVA statistical test used to show the impact of debris on fish yield has shown that there are significant differences between the weight of marine litter and the weight of fish. In addition, there is a correlation relationship between the weight of marine litter and the weight of fish, and another relationship has been detected between fish yield and types of waste. When certain types of waste increase in the surrounding environment, for example (Papers, Tissues and Metals) with low density, these materials may migrate near the sea surface and become more accessible to fishing nets, (Table 4).

\begin{tabular}{|c|c|c|c|c|c|c|c|c|}
\hline & $\begin{array}{c}\text { Fishs wieght } \\
\text { (g) }\end{array}$ & $\begin{array}{c}\text { Wastes } \\
\text { wieght (g) }\end{array}$ & Plastic & Metal & Glass & Rubber & $\begin{array}{c}\text { Paper } \\
\text { Lumber }\end{array}$ & Cloth \\
\hline $\begin{array}{c}\text { Fishs weight }(\mathrm{g}) \text { Pearson } \\
\text { correlation } \\
\text { Sig (2-tailed) } \\
\mathrm{N}\end{array}$ & 1 & $\begin{array}{c}.427 * \\
.019 \\
30\end{array}$ & $\begin{array}{c}.145 \\
.444 \\
30\end{array}$ & $\begin{array}{c}.057 \\
.765 \\
30\end{array}$ & $\begin{array}{c}\mathrm{b} \\
\cdot \\
30\end{array}$ & $\begin{array}{c}.239 \\
203 \\
30\end{array}$ & $\begin{array}{c}544^{* *} \\
.002 \\
30\end{array}$ & $\begin{array}{c}.006 \\
.974 \\
30\end{array}$ \\
\hline $\begin{array}{c}\text { Wastes weight }(\mathrm{g}) \text { Pearson } \\
\text { correlation } \\
\text { Sig }(2 \text {-tailed }) \\
\mathrm{N}\end{array}$ & & 1 & $\begin{array}{c}.251 \\
.181 \\
30\end{array}$ & $\begin{array}{c}.488^{*} \\
.013 \\
30\end{array}$ & $\begin{array}{c}\mathrm{b} \\
. \\
30\end{array}$ & $\begin{array}{c}.336 \\
.070 \\
30\end{array}$ & $\begin{array}{c}.603^{* *} \\
.000 \\
30\end{array}$ & $\begin{array}{c}.657^{* *} \\
.000 \\
30\end{array}$ \\
\hline $\begin{array}{c}\text { Plastic weight }(\mathrm{g}) \text { Pearson } \\
\text { correlation } \\
\text { Sig (2-tailed) } \\
\mathrm{N}\end{array}$ & & & 1 & $\begin{array}{l}.224 \\
.235 \\
30\end{array}$ & $\begin{array}{c}\mathrm{b} \\
\cdot \\
30\end{array}$ & $\begin{array}{c}.196 \\
.299 \\
30\end{array}$ & $\begin{array}{c}.118 \\
.534 \\
30\end{array}$ & $\begin{array}{c}.196 \\
.299 \\
30\end{array}$ \\
\hline $\begin{array}{c}\text { Metal weight }(\mathrm{g}) \text { Pearson } \\
\text { correlation } \\
\text { Sig }(2 \text {-tailed }) \\
\mathrm{N}\end{array}$ & & & & 1 & $\begin{array}{c}\mathrm{b} \\
\dot{3} \\
30\end{array}$ & $\begin{array}{c}.351 \\
.057 \\
30\end{array}$ & $\begin{array}{c}.035 \\
.853 \\
30\end{array}$ & $\begin{array}{c}.351 \\
.057 \\
30\end{array}$ \\
\hline $\begin{array}{c}\text { Glass weight }(\mathrm{g}) \text { Pearson } \\
\text { correlation } \\
\text { Sig }(2 \text {-tailed }) \\
\mathrm{N}\end{array}$ & & & & & 1 & $\begin{array}{c}\mathrm{b} \\
\cdot \\
30\end{array}$ & $\begin{array}{c}\mathrm{b} \\
\cdot \\
30\end{array}$ & $\begin{array}{c}\mathrm{b} \\
. \\
30\end{array}$ \\
\hline $\begin{array}{c}\text { Rubber weight }(\mathrm{g}) \text { Pearson } \\
\text { correlation } \\
\text { Sig }(2 \text {-tailed }) \\
\mathrm{N}\end{array}$ & & & & & & 1 & $\begin{array}{c}.015 \\
.935 \\
30\end{array}$ & $\begin{array}{c}.135 \\
.478 \\
30\end{array}$ \\
\hline
\end{tabular}




\begin{tabular}{|c|c|c|c|c|c|c|}
\hline $\begin{array}{c}\text { Paper weight (g) Pearson } \\
\text { correlation } \\
\text { Sig (2-tailed) }\end{array}$ & & & .247 \\
$\mathrm{~N}$ & & & \\
\hline $\begin{array}{c}\text { Cloth weight (g) Pearson } \\
\text { correlation } \\
\text { Sig (2-tailed) }\end{array}$ & & & & \\
$\mathrm{N}$ & & & & \\
\hline
\end{tabular}

\section{Conclusions}

The impacts of marine litter on the environment are both direct and indirect, affecting primarily marine organisms, and subsequently, the performance of the fishery in general. The ingestion of microscopic debris $(<5 \mathrm{~mm})$ by marine organisms is considered more and more a phenomenon of great ecological concern. Marine organisms through direct or indirect contact can suffer from entanglements, suffocation, and strangulation. Chemical effects on health caused by microplastic, as well as the cumulation of waste in the seafloor, some of the main reasons contributing to the occurrence of damage to marine life. In addition to the emergence of large amounts of waste in fishing nets.

\section{Acknowledgment}

First, we wish to express our thanks to our colleagues in the laboratory: group of Conservation Biological Systems and Laboratory of Applied Biology and pathology. Pr. Youns saoud hat provided us with the necessary working materials to carry out this study, as well as any necessary information. Without forgetting to thank warmly the volunteers fisherman, the Maritime Fishing Office and Fnideq association for the underwater Sports. Mr. Ridwan Backouri wich constantly helps us, with the collection phase of data on the beach of M'diq, and that, without their efforts, the work will not be performed.

\section{References}

1. Aksissou M, Benhardouze W, Saoud Y. Impact de la Pollution sur les échouages des tortues marines au NW du Maroc. Proceedings du Journée d'Etude sur la Pollution Marine, Tanger, Fondation Sigma. 2006:91-96.

2. Andrady AL. Plastics and the Environment. New Jersey: John Wiley \& Sons, Inc. 2003.

3. Arthur C, Baker J, Bamford H. Proceedings of the International Research Workshop on the Occurrence, Effects, and Fate of Micro plastic Marine Debris. 2009.

4. Maryvonne HENRY. Pollution du milieu marin par les déchets solides : Etat des connaissances Perspectives d'implication de l'Ifremer en réponse au défi de la Directive Cadre Stratégie Marine et du Grenelle de la Mer. Direction Prospective et Stratégie Scientifique Mai 2010 RST.DOP/LER-PAC/10-09. 2010.

5. Auman HJ, Woehler EJ, Riddle MJ, Burton H. First evidence of ingestion of plastic debris by seabirds at sub-Antarctic Heard Island. Marine Ornithology. 2004;32(1):105-106.
6. Avery Gomm S, O Hara PD, Kleine L, Bowes V, Wilson LK, Barry KL. Northern fulmars as biological monitors of trends of plastic pollution in the eastern North Pacific. Marine Pollution Bulletin. 2012;64(9):17761781.

7. Azzarello MY, Van-Vleet ES. Marine birds and plastic pollution. Mar Ecol Prog Ser. 1987;37:295-303.

8. Baird RW, Hooker SK. Ingestion of plastic and unusual prey by a juvenile harbor porpoise. Marine Pollution Bulletin. 2000;40(8):719720.

9. Balance A, Ryan PG, Turpie JK. How much is a clean beach worth? The impact of litter on beach users in the Cape Peninsula, South Africa. South African Journal of Science. 2000;96(5):210-213.

10. Barnes DK. Biodiversity-Invasions by marine life on plastic debris. Nature. 2002;416(6883):808-809.

11. Barreiros JP, Barcelos J. Plastic ingestion by a leatherback turtle Dermochelys coriacea from the Azores (NE Atlantic). Marine Pollution Bulletin. 2001;42(11):1196-1197.

12. Battaglia P, Andaloro F, Consoli P, Esposito V, Malara D, Musolino S, et al. Feeding habits of the Atlantic bluefin tuna, Thunnus thynnus (L. 1758), in the central Mediterranean Sea (Strait of Messina). Helgoland Marine Research. 2013;67(1):97-107.

13. Bello GE, Anfuso GM, Maciasa AB, Benavente JG, Barragan JMM, Nachite D. Etudes préliminaires en vue d'une proposition de gestion intégrée pour les côtes méditerranéenne du littoral marocain : la portion Ceuta-Cabo Negro. DL : CA-123/2006 (Espagne). 2006:107.

14. Besseling E, Wegner A, Foekema EM, van den Heuvel-Greve MJ, Koelmans AA. Effects of Micro plastic on Fitness and PCB Bioaccumulation by the Lugworm Arenicola marina (L.). Environ Sci Technol. 2013;47(1):593-600. doi: 10.1021/es302763x

15. Bhagat RP. On Co-Incidence of Plastic (Polythene) Grains in the Gizzard of Semi-Wild (Freely Inhabiting) Common Rock Pigeon, Columba livia intermedia, Linnaeus, 1758, in Biratagar, Nepal. Tribhuvan Univ J. 2009;26(1):81-84.

16. Bhattacharya P, Lin S, Turner JP, Ke PC. Physical Adsorption of Charged Plastic Nanoparticles Affects Algal Photosynthesis. J Phys Chem C. 2010;114(39):16556-16561.

17. Boerger CM, Lattin GL, Moore SL, Moore CJ. Plastic ingestion by planktivorous fishes in the North Pacific Central Gyre. Marine Pollution Bulletin. 2010;60(12):2275-2278. doi: 10.1016/j. marpolbul.2010.08.007

18. Browne MA, Dissanayake A, Galloway TS, Lowe DM, Thompson RC. Ingested Microscopic Plastic Translocates to the Circulatory System of the Mussel, Mytilus edulis (L.). Environ Sci Technol. 2008;42(13):50265031. 
19. Collette B, Christopher RA. Revision of the frigate tunas (Scombridae, Auxis], with descriptions of two new Subspecies from the eastern Pacific. Fishery Bulletin. 1996;94:423-441.

20. Choy CA, Drazen JC. Plastic for dinner? Observations of frequent debris ingestion by pelagic predatory fishes from the central North Pacific Marine Ecology Progress Series. 2013;485:155-163.

21. Cliff G, Dudley SFJ, Ryan PG, Singleton N. Large sharks and plastic debris in KwaZulu-Natal, South Africa. Marine and Freshwater Research. 2002;53:575-581.

22. Coe JM, Rogers D. Marine debris: sources, impacts and solutions Springer. 1997.

23. Cole M, Lindeque P, Fileman E, Halsband C, Goodhead R, Moger J, et al. Microplastic Ingestion by Zooplankton. Environ Sci Technol. 2013;47(12):6646-6655.

24. Cole M, Webb H, Lindeque PK, Fileman ES, Halsband C, Galloway TS, Isolation of microplastics in biota-rich seawater samples and marine organisms. Sci Rep. 2014:4.

25. Collette BB, Scombridae Atunes, bacoretas, bonitos, caballas, estorninos, melva, etc. In: Fischer W, Krupp F, Schneider W, Sommer C, Carpenter KE, Niem VH (Ed.). Guia para la identification de especies para los fines de la pesca. 1995:1521-1543.

26. Miranda DDA, Carvalho-Souza GFD. Are we eating plastic-ingesting fish? Marine Pollution Bulletin. 2015;103(1-2):109-114.

27. Dantas DV, Barletta M, da Costa MF. The seasonal and spatial patterns of ingestion of polyfilament nylon fragments by estuarine drums (Sciaenidae). Environ Sci Pollut Res Int. 2012;19(2):600-606. doi: 10.1007/s11356-011-0579-0

28. Deepak V, Akshay K, Sandeep V, Chaitanya R. Description of a new species of Sitana Cuvier, 1829 from southern India. Zootaxa. 2016;4139(2):167-182.

29. Derraik JGB. The pollution of the marine environment by plastic debris: a review. Marine Pollution Bulletin. 2002;44(9):842-852.

30. Di Natale A, Mangano A. New data on catch composition of Atlantic bonito (Sarda sarda, Bloch, 1793) in the Tyrrhenian Sea and in the Strait of Sicily. Collect Vol Sci Pap. 2009;64(7):2192-2199.

31. Driss N. Etienne B, Nick M, Fouad Z. «Planlocal GIZC Pour la Prefecture Littorale de M'DIQ-FNIDEQ. 2009:1-4.

32. Eriksen M, Maximenko N, Thiel M, Cummins A, Lattin G, Wilson S, et al. Plastic pollution in the South Pacific subtropical gyre. Marine Pollution Bulletin. 2013;68(1-2):71-76.

33. Fendall LS, Sewell MA. Contributing to marine pollution by washing your face: microplastics in facial cleansers. Mar Pollut Bull. 2009;58(8):1225-1228.

34. Foekema EM, de Gruijter C, Mergia MT, van Franeker JA, Murk AJ, Koelmans AA. Plastic in North Sea fish. Environ Sci Technol. 2013;47(15):8818-8824. doi: 10.1021/es400931b

35. Galgani F, Leaute JP, Moguedet P, Souplet A, Verin Y, Carpentier A, et al. Litter on the Sea Floor Along European Coasts. Marine Pollution Bulletin. 2000;40(6):516-527.

36. Gall SC, Thompson RC. The impact of debris on marine life. Mar Pollut Bull. 2015;92(1-2):170-179.

37. Gray JS. Marine biodiversity: patterns, threats and conservation needs. Biodiversity and Conservation. 1997;6(1):153-175.
38. Gregory MR. Environmental implications of plastic debris in marine settings - entanglement, ingestion, smothering, hangers-on, hitchhiking and alien invasions. Philosophical Transactions of the Royal Society B. 2009;364(1526):2013-2026.

39. Gregory MR. Environmental implications of plastic debris in marine settings entanglement, ingestion, smothering, hangerson, hitch-hiking and alien invasions. Philos Trans R Soc B Biol Sci. 2009;364(1526):2013-2025.

40.Grudtsev ME, Korolevich LI. Studies of frigate tuna Auxis thazard (Lacepede) age and growth in the eastern part of the Equatorial Atlantic. Col Vol Sci Pap. ICCAT. 1986;25(2):269-274.

41. Hannahrose N, David H, Carol K, Jenny S, Michelle MH, Jim H. Seabirds as indicators of plastic pollution in the North Pacific. Plastic Debris Rivers to the Sea Conference, Redondo Beach. 2005:1-37.

42. Harley CD, Hughes RA, Hultgren KM, Miner BG, Sorte CJ, Thornber CS, et al. The impacts of climate change in coastal marine systems. Ecology Letters. 2006;9(2):228-241. doi: 10.1111/j.1461-0248.2005.00871.x

43. Heskett M, Takada H, Yamashita R, Yuyama M, Ito M, Geok YB, et al. Measurement of persistent organic pollutants (POPs) in plastic resin pellets from remote islands: toward establishment of background concentrations for International Pellet Watch. Mar Pollut Bull. 2012;64(2):445-448. doi: 10.1016/j.marpolbul.2011.11.004

44. Holmes LA, Turner A, Thompson RC. Adsorption of trace metals to plastic resin pellets in the marine environment. Environmental Pollution. 2012;160(1):42-48. doi: 10.1016/j.envpol.2011.08.052

45. Impacts of Marine Debris on Biodiversity 2012: Current Status and Potential Solutions Published by the Secretariat of the Convention on Biological Diversity in collaboration with the Scientific and Technical Advisory Panel-GEF CBD Technical Series No. 67

46. IUCN. IUCN Red List of Threatened Species (ver. 2011.2). 2011.

47. Laist DW. Impacts of marine debris: entanglement of marine life in marine debris including a comprehensive list of species with entanglement and ingestion records. In: Coe JM, Rogers DB. (Eds.), Marine Debris: sources, impacts, and solutions. Springer Series on Environmental Management. 1997:99-139.

48. Law KL, Moret-Ferguson S, Maximenko NA, Proskurowski G, Peacock EE, Hafner J, et al. Plastic accumulation in the North Atlantic subtropical gyre. Science. 2010;329(5996):1185-1188. doi: 10.1126/ science.1192321

49. Lucas Z. Monitoring persistent litter in the marine environment on Sable Island, Nova Scotia. Marine Pollution Bulletin. 1992;24(4):192199.

50. Lusher AL, McHugh M, Thompson RC. Occurrence of microplastics in the gastrointestinal tract of pelagic and demersal fish from the English Channel. Marine Pollution Bulletin. 2013;67(1-2):94-99.

51. Mato Y, Isobe T, Takada H, Kanehiro H, Ohtake C, Kaminuma T. Plastic resin pellets as a transport medium for toxic chemicals in the marine environment. Environmental Science \& Technology. 2001;35(2):318324.

52. Matsuoka T, Nakashima T, Nagasawa N. A review of ghost fishing: scientific approaches to evaluation and solutions. Fisheries Science. 2005;71(4):691-702.

53. Mcllgorm A, Campbell HF, Rule MJ. The economic cost and control of marine debris damage in the Asia-Pacific region. Ocean \& Coastal Management. 2011;54(9):643-651. 
54. Phillips MB, Bonner TH. Occurrence and amount of micro plastic ingested by fishes in watersheds of the Gulf of Mexico. Marine Pollution Bulletin. 2015;100(1):264-269. doi: 10.1016/j. marpolbul.2015.08.041

55. Molnar JL, Gamboa RL, Revenga C, Spalding MD. Assessing the global threat of invasive species to marine biodiversity. Frontiers in Ecology and the Environment. 2008;6(9):485-492.

56. Morocco Punta Almina to Oued Kiss, 2012, Sector 5, retrieved 16 November. (https://www.google.com/search Morocco, Punta Almina Oued Kiss 2012)

57. Mouat T, Lopez-Lozano R, Bateson H. Economic impacts of Marine litter. KIMO (Kommunenes Internasjonale Miljoorganisasjon). 2010:105.

58. Mrosovsky N, Geraldine DR, Michael CJ. Leatherback turtles: The menace of plastic. Marine Pollution Bulletin. 2009;58:287-289.

59. Murray F, Cowie PR. Plastic contamination in the decapod crustacean Nephrops norvegicus (Linnaeus, 1758). Mar Pollut Bull. 2011;62(6):1207-1217. doi: 10.1016/j.marpolbul.2011.03.032

60. National Oceanic and Atmospheric Administration (NOAA) "Ecological Effects of Fishing" by Stephen K, Brown Peter J, Auster Liz Lauck, Michael Coyne. NOAA's State of the Coast Report. Silver Spring. 1998.

61. Occhipinti-Ambrogi A. Global change and marine communities: Alien species and climate change. Marine Pollution Bulletin. 2007;55(79):342-352.

62. Ocean Conservancy 2010. Trash Travels: From our hands to the sea, around the glove, and through time. International Coastal Cleanup Report 2.

63. Ofiara DD. Assessment of economic losses from marine pollution: An introduction to economic principles and methods. Mar Pollut Bull. 2001;42(9):709-725.

64. Pajuelo JG, Lorenzo JM, Dominguez R, Ramos A, Gregoire M. On the population ecology of the zebra seabream Diplodus cervinus cervinus (Lowe 1838) from the coasts of the Canarian archipelago, North West Africa. Environmental Biology of Fishes. 2003;67(4):407-416.

65. Possatto FE, Barletta M, Costa MF, do Sul JA, Dantas DV. Plastic debris ingestion by marine catfish: an unexpected fisheries impact. Mar Pollut Bull. 2011;62(25):1098-1102. doi: 10.1016/j.marpolbul.2011.01.036

66. Ramos JAA, Barletta M, Costa MF. Ingestion of nylon threads by Gerreidae while using a tropical estuary as foraging grounds. AQUATIC BIOLOGY. 2012;17:29-34.

67. RGPH 2014. Population legale des Régions, Provinces, Préfectures, Municipalités, Arrondissements et Communes du Royaume d'aprés les Résultats du RGPH 2014 (16 régions)

68. Ribic CA, Ganio LM. Power analysis for beach surveys of marine debris. Marine Pollution Bulletin. 1996;32(7):554-557.

69. Richards ZT, Beger M. A quantification of the standing stock of macro-debris in Majuro lagoon and its effect on hard coral communities. Mar Pollut Bull. 2011;62(8):1693-1701. doi: 10.1016/j. marpolbul.2011.06.003

70. Robertson DR, Cramer KL. Shore fishes and biogeographic subdivisions of the Tropical Eastern Pacific. MARINE ECOLOGY PROGRESS SERIES. 2009;380:1-17.
71. Romeo T, Pietro B, Pedà C, Consoli P, Andaloro F, Fossi MC. First evidence of presence of plastic debris in stomach of large pelagic fish in the Mediterranean Sea. Mar Pollut Bull. 2015;95(1):358-361. doi: 10.1016/j.marpolbul.2015.04.048

72. Ryan PG, Moore CJ, van Franeker JA, Moloney CL. Monitoring the abundance of plastic debris in the marine environment. Philos Trans R Soc Lond B Biol Sci. 2009;364(1526):1999-2012. doi: 10.1098/ rstb.2008.0207

73. Ryan PG, Bouwman H, Moloney CL, Yuyama M, Takada H. Long-term decreases in persistent organic pollutants in South African coastal waters detected from beached polyethylene pellets. Mar Pollut Bull. 2012;64(12):2756-2760. doi: 10.1016/j.marpolbul.2012.09.013

74. Schuyler Q Hardesty BD, Wilcox C, Townsend K. Global analysis of anthropogenic debris ingestion by sea turtles. Conserv Biol. 2013;28(1):129-139.

75. Secretariat of the Convention on Biological Diversity and the Scientific and Technical Advisory Panel (GEF). Impacts of marine debris on biodiversity: current status and potential solutions. 2012;67:61.

76. Setala O, Fleming-Lehtinen V, Lehtiniemi M. Ingestion and transfer of microplastics in the planktonic food web. Environ Pollut. 2014;185:7783. doi: 10.1016/j.envpol.2013.10.013

77. Sheavly SB, Register KM. Marine debris \& plastics: Environmental concerns, sources, impacts and solutions. Journal of Polymers and the Environment. 2007;15(4):301-305.

78. Singh B, Sharma NN. Mechanistic implications of plastic degradation. Polymer Degradation and Stability. 2008;93(3):561-584.

79. Sutherland WJ, Clout M, Cote IM, Daszak P, Depledge MH, Fellman L, et al. A horizon scan of global conservation issues for 2010. Trends Ecol Evol. 2010;25(1):1-7. doi: 10.1016/j.tree.2009.10.003

80. Teuten EL, Saquing JM, Knappe DR, Barlaz MA, Jonsson S, Björn A, et al. Transport and release of chemicals from plastics to the environment and to wildlife. Philos Trans R Soc Lond B Biol Sci. 2009;364(1526):2027-2045. doi: 10.1098/rstb.2008.0284

81. Thompson RC, Moore CJ, vom Saal FS, Swan SH. Plastics, the environment and human health: current consensus and future trends. Philos Trans R Soc Lond B Biol Sci. 2009;364(1526):2153-2166. doi: 10.1098/rstb.2009.0053

82. Van der Laan R, Eschmeyer WN, Fricke R. Family-group names of Recent fishes. Zootaxa Monograph. 2014;3882(2):1-230.

83. Van Franeker JA, Blaize C, Danielsen J, Fairclough K, Gollan J, Guse N, et al. Monitoring plastic ingestion by the northern fulmar Fulmarus glacialis in the North Sea. Environmental Pollution. 2011;159(10):2609-2615.

84. Von Moos N, Burkhardt-Holm P, Kohler A. Uptake and Effects of Microplastics on Cells and Tissue of the Blue Mussel Mytilus edulis L. after an Experimental Exposure. Environ Sci Technol. 2012;46(20):11327-11335. doi: 10.1021/es302332w

85. Winkler AC, Santos CV, Potts WM. Diagnosing the sexual pattern of Diplodus cervinus hottentotus (Pisces: Sparidae) from southern Angola. African Journal of Marine Science. 2014;36(4):505-512.

86. Wright SL, Thompson RC, Galloway TS. The physical impacts of microplastics on marine organisms: A review. Environmental Pollution. 2013;178:483-492. doi: 10.1016/j.envpol.2013.02.031 